\title{
Bureaucracy defeated at EPA
}

SIR - Dr David Lewis's Commentary article on the US Environmental Protection Agency (EPA)'s science (Nature 381, 731 ; 1996) shows him to be one of the dedicated scientists whose contributions to protecting the environment have been the hallmark of EPA's research and development programme. His frustration and concern clearly come through. However, from my view as an informed outsider who formerly headed EPA's Office of Research and Development (ORD), his Commentary may be misleading as to the direction of changes in recent years.

The current head of ORD, Robert Huggett, is an internationally known environmental scientist who has worked very effectively to deal with the many problems inherent in US bureaucracies, and particularly in those whose regulatory power attracts attention. Bureaucratic brick walls I left behind at EPA a decade ago have crumbled, or ways have been found to drive around them. Under Huggett's leadership, and that of his immediate predecessor Erich Bretthauer, there has been a needed increase in funding for ecological research and a marked improvement in administrative approaches to selecting and promoting scientists and engineers. Peer review and quality assurance have extended ever more deeply into EPA, now even reaching some regulatory offices. The strategic planning process has improved greatly, and by clearly articulating the relationship between EPA's regulatory priorities and its scientific and technical research, Huggett has violated the bureaucrat's rule of avoiding accountability.

By achieving an increase in emphasis on the extramural programme, Huggett and the EPA Administrator, Carol Browner, have enlisted the external scientific community to an amazing extent - they received more than a thousand grant proposals last year. Unfortunately, because of inadequate funding, they could support only a handful of these. The true test of this strategy will come this year. To be successful rather than counterproductive, the extramural programme must be able to obtain further direct dollar support and also to divert funding from noncompetitive private contractors to the competitive peer process. As Lewis correctly points out, the decrease in extramural funding for cooperative agreements to work with university scientists has not been helpful to EPA's intramural laboratory efforts. EPA and its laboratories need to be able to resist the congressional pressure that has forced it to continue laboratory spending on private contractors rather than cooperative agreements and grants.

Lewis is certainly correct in pointing out the frustrations of dealing with heavy- handed bureaucratic rules that may be appropriate, if at all, to ensure that the taxpayer gets the highest quality at the lowest price for the purchase of tanks or of toilet paper. My impression, however, is that this negative phenomenon of the early 1990s has eased in the past few years, in part because of principled resistance by EPA scientists who have won their cases, although not without great cost to them and to their colleagues. The success of the present EPA leadership in decreasing the burden on scientist-administrators is supported by the decrease in new directives since its peak in 1993. The continuing reorganization of ORD is likely to continue the increase in the ratio of scientists to administrators.

There is no disagreement with Lewis's metaphor about building a scientifically sound foundation for environmental protection. But he is in error on the issue of building the actual foundation for a new laboratory complex in Research Triangle Park, North Carolina. In 1985 I failed to convince the Office of Management and Budget of the need for a new centralized research building in North Carolina to replace inadequate and expensive leased sites. It is good news that EPA leadership has finally accomplished this feat.

Bernard D. Goldstein

Environmental and Occupational Health Sciences Institute,

PO Box 1179,

Piscataway, New Jersey 08855-1179, USA

\section{Hot biology papers}

SIR - An analysis of highly cited ('hot') papers in biology, published mainly in Nature, Science and Cell, reveals that the selected hot papers have more authors, more institutions and more funding sources than other papers. For the study, I analysed 16 issues, 71 papers identified by Science Watch between 1993 and 1995. I excluded six hot papers with 20 or more authors. I compared 65 hot papers with 414 papers in 28 issues of the three leading journals that contained at least one hot paper.

My analysis reveals that the mean number of authors per hot paper is 6.54 for
Nature, 6.62 for Cell and 7.71 for Science, whereas the mean number of authors per paper varies between 4.36 and 4.66. There seems to be a distinct trend towards more authors as compared to earlier findings ${ }^{1}$.

The mean number of institutions per paper is defined as papers listing more than one institution participating in the research. The table shows that the mean number of institutions per paper is 2.06 for Science, 1.91 for Nature and 1.72 for Cell. The proportion of multi-institutional papers is higher in the hot papers than in the rest.

Funding is known to be associated with multiple authorship ${ }^{2-4}$. My data show that there is considerable variation in the mean number of funding sources for two different groups. When I analysed the data according to the funding sources, I found that papers reporting four or more funding sources have more authors (for example, in Science, 7.7 authors and 8.6 authors in hot papers compared with 4.4 and 6.0 authors for the rest).

Zhang Haiqi

National Institute for the Control of Pharmaceutical and Biological Products, Beijing 100050, China

1. Satyanarayana, K. \& Ratnakar, K. V. Scientometrics 17 363-371 (1989).

2. Price, D. J. de S. Science 212, 986 (1981).

3. Pao, M. L. Inform. Process. Manag. 28, 99-109 (1992)

4. Mussarakis, S. Am. J. Roentgenol. 163, 973-979 (1994)

Present address: Medical Information Center for Education and Research, Jikei University School of Medicine, 3-25-8 Nishi-shinbashi, Minato-ku, Tokyo 105, Japan.

\begin{tabular}{|c|c|c|c|c|c|c|c|c|c|}
\hline \multicolumn{10}{|c|}{ DISTRIBUTION OF PAPERS BY THE MEAN NUMBER OF AUTHORS, INSTITUTIONS AND FUNDING SOURCES } \\
\hline Periodicals & Papers & Authors & $\begin{array}{l}\text { Mean no. } \\
\text { of authors }\end{array}$ & Institutions & $\begin{array}{l}\text { Multi-institutional } \\
\text { papers (\%) }\end{array}$ & $\begin{array}{l}\text { Mean no. } \\
\text { of institutions }\end{array}$ & $\begin{array}{l}\text { Funding } \\
\text { sources }\end{array}$ & $\begin{array}{c}\text { Funded } \\
\text { papers (\%) }\end{array}$ & $\begin{array}{c}\text { Mean no. of } \\
\text { funding sources }\end{array}$ \\
\hline \multicolumn{10}{|l|}{ Nature } \\
\hline Hot papers in biology & 24 & 157 & 6.54 & 54 & 79.17 & 2.25 & 78 & 83.34 & 3.25 \\
\hline Articles/Letters to Nature & 152 & 663 & 4.36 & 291 & 59.48 & 1.91 & 295 & 75.66 & 1.94 \\
\hline \multicolumn{10}{|l|}{ Cell } \\
\hline Hot papers in biology & 21 & 139 & 6.62 & 45 & 66.67 & 2.14 & 72 & 90.47 & 3.43 \\
\hline Articles & 139 & 632 & 4.55 & 225 & 44.61 & 1.62 & 381 & 97.12 & 2.74 \\
\hline \multicolumn{10}{|l|}{ Science } \\
\hline Hot papers in biology & 14 & 108 & 7.71 & 46 & 85.71 & 3.28 & 53 & 92.86 & 3.78 \\
\hline Research articles/Reports & 123 & 542 & 4.41 & 254 & 58.06 & 2.06 & 290 & 83.74 & 2.35 \\
\hline $\begin{array}{l}\text { PNAS (US) etc. } \\
\text { Hot papers in biology }\end{array}$ & 6 & 28 & 4.66 & 9 & & 1.50 & 18 & & 3.00 \\
\hline
\end{tabular}

